\title{
Bond strength of metal brackets to feldspathic ceramic treated with different surface conditioning methods: an in vitro study *
}

\section{Purpose}

To compare MEP which is originally manufactured for increasing bond strength between organic resins and ceramic with conventional surface treatment methods in preparation of leucite-reinforced FC surfaces regarding shear bond strength (SBS) of stainless steel brackets and the mode of bond failure.

\section{Materials and Methods}

Forty specimens that were fabricated from $\mathrm{FC}$ material and glazed were randomly assigned to four surface conditioning methods: (1) CoJet Sand; (2) MEP; (3) HF acid etching followed by silane coupling agent; (4) Diamond bur followed by silane coupling agent. The SBS was determined using universal testing machine. Bond failure sites were classified according to Adhesive Remnant Index (ARI).

\section{Results}

No statistically significant difference $(p>0.05)$ was found in SBS between the groups while significant intergroup differences were detected concerning ARI scores $(p<0.001)$. Group 1 had ARI score 1 and 2 indicating mode of failure at the adhesive interface with greater percentage of the adhesive left on bracket base. The other groups had higher frequency of ARI score 3 and 2. The quantity of the ARI retained on the ceramic surface was highest in Group 3, followed by Group 4 and Group 2.

\section{Conclusion}

MEP can be a suitable alternative for bonding metal brackets to FC surface.

Keywords: Surface treatment methods, Adhesion, Bond performance, Feldspathic ceramic

\section{Introduction}

According to American Association of Orthodontists' a 16\% rise was observed from 2012 to 2014 in the number of adult patients seeking orthodontic treatment with an estimate of more than a quarter of the orthodontic patients being adults (1). Complexity of the aging dentition due to loss of dental integrity entails restoration of impaired function and compromised esthetics. Dental ceramics have been the materials of choice for their esthetic properties and an orthodontist might not know if it is feldspathic ceramic (FC), aluminous ceramic, or glass ceramic. Leucite-reinforced FC is commonly used in ceramic-fused-to-metal restorations (2). Also, leucite-reinforced FC has been used in anterior restorations for its superior esthetic properties, as it provides a better depth of translucency that best mimics the optical properties of enamel and dentin among dental ceramics (3). Also, on veneer metal frameworks, it presents with a coefficient of thermal expansion compatible with that of the metal substructure (4). However, the bond strength of composite resins to ceramic restorations has often been noted to be unsatisfactory. It was reported that bracket failures prolonged the treatment duration significantly with

\author{
Duygu Recen ${ }^{1}$ (D), \\ Bengisu Yildirim ${ }^{2}$, \\ Eman Othman ${ }^{3}$ (D), \\ Erhan Comlekoglu ${ }^{4}$ iD, \\ Isil Aras ${ }^{3}$
}

ORCID IDs of the authors: D.R. 0000-0003-0613-386X B.Y. 0000-0002-9208-5827; E.O. 0000-0001-8454-7959; M.E.C.. 0000-0002-0915-5821; I.A. 0000-0003-2916-9697

*This study was presented as an oral presentation at American Association of Orthodontics 2019 Annual Session, May 3-7 Los Angeles, CA, USA.

'Izmir Democracy University, Faculty of Dentistry, Department of Restorative Dentistry, Izmir, Turkey

${ }^{2}$ Usak University, Faculty of Dentistry, Department of Prosthodontics, Usak, Turkey

Jacksonville University, Brooks Rehabilitation College of Healthcare Sciences, School of Orthodontics, Jacksonville, FL, USA

${ }^{4}$ Ege University, Faculty of Dentistry, Department of Prosthodontics, Izmir, Turkey

Corresponding Author: Duygu Recen

E-mail: recenduygu@hotmail.com

Received: 8 January, 2020 Revised: 26 February, 2020 Accepted: 21 May, 2020

DOI: 10.26650/eor.20210004 
an average of 0.6 months of additional duration for each loose bracket (5). Therefore, preventing bracket failures appears to be an effective strategy in terms of both patient satisfaction, and clinicians' interest. On the other hand, the optimal bonding of orthodontic brackets to ceramics brings about a risk of damaging the ceramic surfaces if the bond strength of the adhesive exceeds the internal strength of the substrate during removal of bonded brackets with pliers. As a result, bond strength must be high enough to withstand orthodontic forces during the treatment, but low enough to prevent any permanent damage to the ceramic during the debonding procedure. Researchers haven't reached a consensus about shear force limits. However, an orthodontic material should have minimum bond strength of 5-10 MPa to withstand masticatory forces. Also, adhesion forces should not be more than 40-50 MPa to prevent hard tissue loss after debonding. Ideally, bonding force of an orthodontic material should be in the range of 5-50 MPa (6).

Achieving a low bond failure rate should be a high-priority objective, since replacing a loose bracket is time-consuming, a nuisance to the orthodontist and costly. Improving the bonding between orthodontic brackets and ceramic surfaces requires different efforts than that of preparation of enamel surfaces. Deglazing of the ceramic surface creating micro-mechanical retention is recommended for the composite-ceramic bond $(7,8)$. Among the available surface conditioning protocols, hydrofluoric (HF) acid has been known to be caustic and deleterious to soft tissues (9). Sandblasting, on the other hand, predisposes the individual to the inhalation of aluminum oxide-containing aerosol, and thus respiratory diseases (10). Because of these potential detrimental effects on health, clinicians may prefer alternative adhesion promotion modalities. Using burs, on the other hand, promotes crack formation that propagates in time which might result in an eventual failure of a restoration that is actually expected to serve the patient for many years $(11,12)$. Overall, it was reported that even when the ceramic surface was sandblasted, hydrofluoric acid gel treated followed by an application of silane the failure rate was $8.9 \%$ (13). Thus, recent advances in materials and techniques indicate better adhesives, safer alternatives and simpler procedures to provide higher bond strengths.

In the contemporary practice, interdisciplinary treatment approach not only requires collaboration of different specialists, but also incorporating other disciplines' knowledge into one's own treatment strategy. One-bottle systems, are considered to be more economical and to minimize clinician errors during the complex process of bonding. Recently, a self-etching ceramic primer which was originally manufactured for increasing bond strength between organic resins and ceramic in restorative dentistry was introduced. It presents the clinician with the advantage of achieving etching and priming procedures in one-step. One-step techniques reduces the chair time, reduce technique sensitivity, minimizes possible saliva contamination from the clinician point of view, whereas it causes less discomfort for the patient (14). Although few reports have been published concerning the effects of a self-etching ceramic primer on bonding efficiency of resin cements to ceramics, to the authors' best knowledge there has been limited studies to investigate the efficiency of bonding of brackets to FC surfaces treated with a self-etching ceramic primer. Hence the aims of this in-vitro study were (1) to assess the shear bond strength
(SBS) of stainless steel brackets bonded to FC surface treated with 4 different ceramic conditioning methods, (2) to determine the mode of bond failure, and (3) to examining the effect of different surface treatment modalities on ceramic surfaces with scanning electron microscope (SEM).

\section{Materials and Methods}

Forty square specimens (height, $2 \mathrm{~mm}$; width $4 \mathrm{~mm}$ ) were fabricated from FC material (Vita, VM9, Bad Sackingen, Germany) $(n=10)$ and glazed. Specimens were individually embedded in self-cured acrylic resin (Dentsply, Degudent $\mathrm{GmbH}$, Hanau, Germany) using teflon molds, leaving the FC surfaces exposed. These specimens were randomly assigned to four surface conditioning methods.

\section{Group 1}

Sandblasting in the form of tribochemical silica coating was achieved by using an intraoral microblasting unit (3M ESPE, Seefeld, Germany) with $30 \mu \mathrm{m}$ grain size aluminum oxide modified with silisic acid -CoJet Sand (3M ESPE, Seefeld, Germany)from a $10 \mathrm{~mm}$ distance at a pressure of $0.25 \mathrm{MPa}$ for $15 \mathrm{~s}$.

\section{Group 2}

Monobond $^{\circ}$ Etch \& Prime (Ivoclar Vivadent AG, Schaan, Liechtenstein) (MEP) was applied and agitated into the FC surface for $20 \mathrm{~s}$, then allowed to react for another 40 $\mathrm{s}$, rinsed thoroughly with water and air-dried.

\section{Group 3}

FC surfaces were etched with 9\% HF (Ultradent, South Jordan, Utah, USA) for $90 \mathrm{~s}$. Then rinsed and air-dried. Silane coupling agent (Bifix DC Ceramic Bond, VOCO GmbH, Cuxhaven, Germany) was applied for $60 \mathrm{~s}$.

\section{Group 4}

FC surfaces were roughened with a cylindrical diamond bur (Brasseler, Lemgo, Germany) for 3 s. The surface was air-dried. Similar to the $3^{\text {rd }}$ group, silane coupling agent was applied for $60 \mathrm{~s}$.

Rest of the experimental designed was carried sequentially out as follows:

\section{Scanning electron microscopy}

SEM (Phenom proX, Phenom-World BV, Netherlands) was used at an operating voltage of $15 \mathrm{kV}$ and $\mathrm{x} 500$ magnification to determine the topography of FC after surface roughening. Bonding procedure

A self-etching adhesive system, Futurabond $U$ (VOCO $\mathrm{GmbH}$, Cuxhaven, Germany) was applied to each specimen and rubbed for $20 \mathrm{~s}$ using a microbrush and air-dried for at least $5 \mathrm{~s}$, followed by light curing for $10 \mathrm{~s}(1200 \mathrm{~mW} / \mathrm{cm} 23 \mathrm{M}$ ESPE, Elipar S10 LED Curing Light, 3M Unitek, Monrovia, Calif.).

For the purposes of standardization, a resin composite material that was marketed by the same manufacturer of the adhesive system was selected. Bifix QM (VOCO GmbH, Cuxhaven, 
Germany) is a dual-cure resin-based adhesive luting system. It was applied onto the maxillary right central incisor metal bracket (American Orthodontics, Sheboygan, Wisconsin, USA) bases. Brackets were placed onto the FC surface with 200 gram-force as determined by a gauge (E.T.M. Corp., Monrovia, California, USA.). The excess resin was cleaned, and the resin was lightcured for $20 \mathrm{~s}$ each from the mesial and distal sides.

\section{Shear bond strength testing}

To stimulate the effects of moisture and temperature conditions in the oral cavity, the specimens were kept in distilled water at $37^{\circ} \mathrm{C}$ for 24 hours after bonding. Debonding was then performed with a shearing force using a Universal Testing Machine (Mod Dental, Esetron, Turkey) at a crosshead speed of $0.5 \mathrm{~mm} / \mathrm{min}$ to the bracket base at the wings in an occlusogingival direction, until bonding failure occurred. Maximum loads for debonding strength were assessed in newtons (N) and bond strengths were converted to MPa by dividing measured values by the bracket base area $\left(10.87 \mathrm{~mm}^{2}\right)(8,12)$.

\section{Adhesive remnant index}

To evaluate the quantity and localization of residual adhesive after debonding, the Adhesive Remnant Index (ARI) scoring developed by Artun and Bergland (15) was used in the present study. The failure-mode analysis was performed at a magnification of $\times 10$ with a zoom stereoscopic microscope (Nikon, SMZ 1500, Tokyo, Japan), and quantified to fit by the quantity and localization of the adhesive remnant the following 0- 3 score scale:

0 : No adhesive on ceramic

1: Less than $50 \%$ of adhesive remains on ceramic

2: More than $50 \%$ of adhesive remains on ceramic

3: All adhesive remains on ceramic

\section{Statistical analysis}

According to a power analysis with 0.05 level and 90\% power (based on a pooled standard deviation of $0.72 \mathrm{MPa}$ and 1.32 MPa detectable difference) (16), the required minimum sample size was 8 .

Statistical analysis was carried out using SPSS for Windows software (ver. 22.0; SPSS Inc., Chicago, IL, USA). Normal distribution of data was tested by means of the Shapiro-Wilks test. The Levene test was used to check the homogeneity of the variances between the groups. Data was determined to display normal distribution with homogeneous variances. Thus, comparisons between the groups were done using a one-way analysis of variance (ANOVA). ARI score was analyzed by the Fisher's Exact Test.

\section{Results}

Results of one-way ANOVA revealed that the SBS was not significantly different between the groups ( $p>0.05$, Table 2).

SEM images of the treated surfaces of FC show that Groups 1 and 4 displayed rougher surfaces, whereas Group 2 presented with a gentler etch pattern (Figure 1). CoJet sand application resulted in fine surface irregularities with minute white spots appearing on the surface which were the silica
Table 1. Manufacturer and composition of the surface treatment agents tested in the present study

\begin{tabular}{|c|c|c|}
\hline Material & Manufacturer & Composition \\
\hline CoJect ${ }^{\mathrm{TM}}$ Sand & $\begin{array}{c}\text { 3M ESPE, Seefeld, } \\
\text { Germany }\end{array}$ & $\begin{array}{c}\text { 30- } \mu \mathrm{m} \text { silica-modified } \\
\mathrm{Al}_{2} \mathrm{O}_{3} \text { particles }\end{array}$ \\
\hline $\begin{array}{l}\text { Monobond } \\
\text { Etch \& Prime }\end{array}$ & $\begin{array}{l}\text { Ivoclar Vivadent AG, } \\
\text { Schaan, Liechtenstein }\end{array}$ & $\begin{array}{c}\text { Tetrabutyl ammonium } \\
\text { dihydrogen trifluoride, } \\
\text { methacrylated } \\
\text { phosphoric acid ester, } \\
\text { trimethoxysilylpropyl } \\
\text { methacrylate, alcohol, } \\
\text { water }\end{array}$ \\
\hline
\end{tabular}

\begin{tabular}{lcc}
\hline $\begin{array}{l}\text { Bifix DC } \\
\text { Ceramic Bond }\end{array}$ & $\begin{array}{c}\text { VOCO GmbH, } \\
\text { Cuxhaven, Germany }\end{array}$ & $\begin{array}{c}\text { Organic acid, } \\
\text { 3-methacryloxypropyl } \\
\text { trimethoxysilane and } \\
\text { acetone }\end{array}$ \\
\hline Futurabond U & $\begin{array}{c}\text { VOCO GmbH, } \\
\text { Cuxhaven, Germany }\end{array}$ & $\begin{array}{c}\text { Liquid 1: Acidic adhesive } \\
\text { monomer HEMA, BISGMA, } \\
\text { HEDMA, UDMA, Catalyst; } \\
\text { Liquid 2: Ethanol, initiator, } \\
\text { catalyst }\end{array}$ \\
\hline Bifix QM & VoCO GmbH, & $\begin{array}{r}\text { Bis-GMA, DMA, silica } \\
\text { fillers, initiator, pigment, } \\
\text { additives }\end{array}$ \\
\hline
\end{tabular}

Table 2. Shear bond strength values (MPa) of metal brackets bonded on treated ceramic surfaces

\begin{tabular}{cccccc} 
& Group 1 & Group 2 & Group 3 & Group 4 & P value \\
\hline Mean \pm SD & $7.41 \pm 3.05$ & $7.09 \pm 1.26$ & $6.36 \pm 0.94$ & $4.55 \pm 2.86$ & 0.22 \\
\hline
\end{tabular}

particles. Uniform microrough gaps and crevices were evident when pre-treating with $\mathrm{HF}$ as a result of the dissolution of the glassy phase. MEP, on the other hand, resulted in less pronounced etching pattern with erosions on the surface with sporadically appearing pits. Adhesion promotion with bur resulted in deep grooves and rough streaks creating macro retentive areas.

Even though, mixed mode of bond failure (i.e. at the adhesive) were observed in the surface conditioning modalities, significant differences were observed regarding ARI scores of 4 methods under question, the intergroup differences were statistically significant for all the combinations tested ( $\mathrm{p}<0.001$, Table 3$)$. In Group 1, the brackets failed mainly at the ceramic/resin interface. ARI scores were 1 and 2 in $60 \%$ and $40 \%$ of the specimens respectively with the greatest quantity of the AR retained on the bracket base among the study groups. With the other surface modification techniques, the brackets failed mainly at the adhesive/bracket interface. However, particularly in Group 3, adhesive failures were predominantly in the adhesive/bracket interface in which the entire composite was observed to be retained on the ceramic surface in $80 \%$ of the specimens. In the other groups, most of the adhesive was observed to be maintained on the FC surface following debonding. The quantity of the adhesive remnant on the bracket surface was highest in Group 3 followed by Group 4 and 2. 

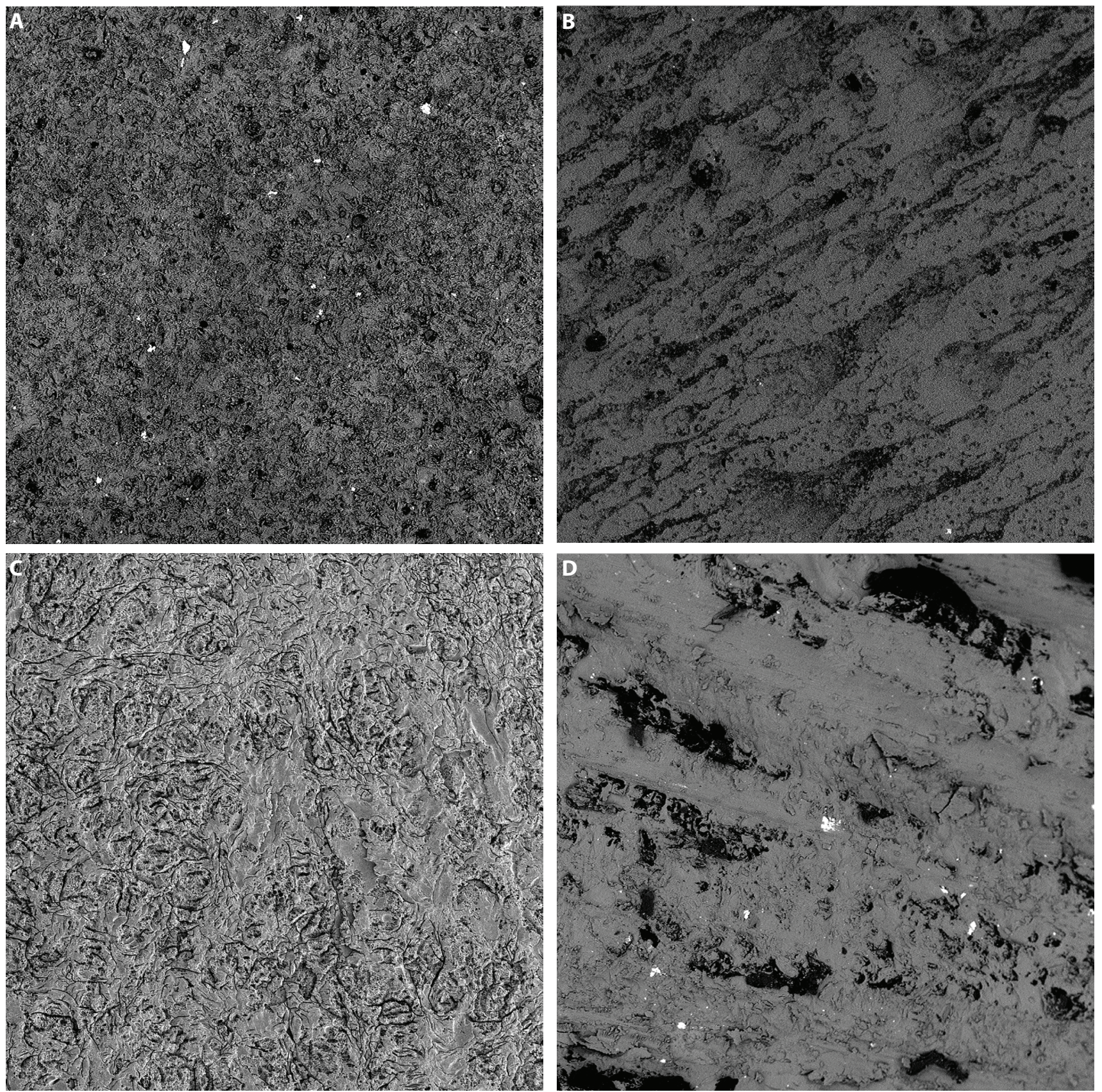

Figure 1. SEM images of CoJet Sand (A), Monobond Etch \& Prime (B), Hydrofluoric Acid (C) and diamond bur (D) treated feldspathic ceramic material.

Table 3. Distribution of Adhesive Remnant Index Scores for the groups

\begin{tabular}{|c|c|c|c|c|c|c|}
\hline \multirow{2}{*}{ Groups } & \multicolumn{4}{|c|}{ ARI Score } & \multirow{2}{*}{$\begin{array}{c}\text { Fisher } \\
\text { Statistics }\end{array}$} & \multirow{2}{*}{$\begin{array}{c}P \\
\text { value }\end{array}$} \\
\hline & 0 & 1 & 2 & 3 & & \\
\hline 1 & $0 \%$ & $60 \%$ & $40 \%$ & $0 \%$ & \multirow{4}{*}{19.854} & \multirow{4}{*}{0.001} \\
\hline 2 & $0 \%$ & $10 \%$ & $40 \%$ & $50 \%$ & & \\
\hline 3 & $0 \%$ & $0 \%$ & $20 \%$ & $80 \%$ & & \\
\hline 4 & $0 \%$ & $0 \%$ & $50 \%$ & $50 \%$ & & \\
\hline
\end{tabular}

\section{Discussion}

The present study was undertaken to evaluate the effect of four different surface conditioning methods on the bond strength and integrity of FC during debonding of metal brackets. The results of this in-vitro study showed that differences in surface treatment techniques did not affect the bond strength significantly. In Group 4 which comprised a combination of diamond bur and silane coupling agent, a mean of $4.55 \mathrm{MPa}$ was recorded which is below the bond strength values of 5-10 MPa that is required to withstand orthodontic forces (6). So, despite no statistically significant differences between groups, Group 4, on average displayed a tendency for less effective bonding of brackets to FC surface. The average shear force necessary to dislodge the metal brackets from the FC surface ranged between 3.49-23.5 $\mathrm{MPa}(7,8,17)$. The SBS values acquired in previous studies were similar to ours. In the previous study (18), that used MEP in preparation of glass ceramics for bonding of orthodontic brackets, the reported mean SBS value was $11.56 \mathrm{MPa}$ which was higher compared with the adhesion strength acquired in this study.

Removing the glaze layer to facilitate bonding by enhancing the surface area has been reported to weaken the FC by reducing the transverse strength $(19,20)$, which can also contribute to the risk of ceramic fracture when the bracket disengages from the ceramic surface. During debonding, 
adhesive failures are preferred over cohesive fractures to avoid ceramic damage. Thurmond et al. (21) stated that cohesive fracture of the ceramic can occur when debonding force is higher than $13 \mathrm{MPa}$. In this study although the FC surfaces were deglazed to increase micromechanical retention, mean SBS values in the groups did not exceed $13 \mathrm{MPa}$, thus it can be said that composite resin-ceramic compound was not stronger than the ceramic itself.

Tribochemical silica coating is a surface treatment method which creates micromechanical retention sites on the ceramic surface to increase adhesion to metal brackets $(12,22)$. Highest SBS values were acquired in Group 1. In line with this finding, the SEM images of the surface treatment methods revealed fine surface irregularities in Group 1 that did not contain a large number of undercuts. Since, in previous studies $(23,24)$, cohesive fracture sites were reported to occur in ceramic when silane agent was used in combination with sandblasting, in the current study silane coupling agent was not applied after tribochemical silica coating for prevention of the cohesive failure of ceramic surfaces.

The mean SBS values acquired with air-abrasion was followed by values obtained using MEP application. Although treatment with MEP was expected to provide lower SBS values compared to HF treatment due its lower acidic concentration (18), the opposite was true for the current study. MEP contains polyflouoride for etching, and it has been indicated that the bond between silica and fluoride is extremely strong (25). This could in turn lead to silica particles in FC to effectively bond to ammonium tri-fluoride in MEP. Together with the trimethoxpropyl methacrylate incorporated in its primer for silanization, it is possible that the anticipated effect of weak acid was overcome. This finding of our also agrees with Lyann et al.'s study (26) who reported comparable and occasionally higher values using MEP between FC restorations and composites, unlike Asiry et al.'s study (18). SEM images of Group 2 demonstrated less roughness and shallower etching pattern than HF group with erosions and randomly appearing superficial and shallow pits which could, again be associated with ammonium polyfluoride which is incorporated in the MEP having a milder acidity but still causing dissolution of the glass phase from the ceramic material.

Silanes increase the wettability of the surfaces with bonding agents and provide a chemical link between dental ceramic and composite resins (27). Thus, in Groups 3 and 4 silanes were also incorporated as adhesion promoters. HF acid etching has been shown to significantly improve the bond strengths for FC by a chemical conditioning that improves the micromechanical retention by dissolving the crystalline and the glassy phases of the ceramic (28). The effect of treatment with HF was clear in the surface topography with an increased surface roughness in terms of scratch-like gaps because of a greater loss of glassy phase when compared with the Group 2.

To the best of our knowledge, Asiry et al. (18) was the first to utilize MEP for orthodontic purposes for bonding braces on lithium disilicate. While high-strength lithium disilicate ceramics are chosen for posterior restorations, more esthetic translucent feldspathic ceramics are opted for anterior restorations (29). Our SBS results were lower than Asiry et al.'s study (18) which same surface treatment methods - namely HF acid etching and MEP- were used for adhesion promotion on lithi- um disilicate ceramics. Despite identical steps taken in surface conditioning, the reported superior bonding performance of resin materials could be attributed to better chemical interaction between hydrophobic resin and the lithium disilicate surface rather than the mechanical interlocking to the rough surface (27), and as an outcome of microstructural and processing differences between two kinds of ceramics (7). Also, it was reported in a recent meta-analysis that greater crosshead speed led to increased bond strength readings. Shearing force was applied $1 \mathrm{~mm} / \mathrm{min}$ in Asiry et al.'s study compared with the $0.5 \mathrm{~mm} / \mathrm{min}$ pace in the current research. Aforementioned study's ARI readings were in agreement with the current study with most of the specimens belonging to scores 2 and 3 before thermocycling.

It was mentioned that diamond bur alone is incapable creating enough retention when bonding brackets to ceramic surface (24). Therefore, in this study it was used in combination with silane to increase SBS values, however findings were still not in the range of acceptable bond values (5-10 MPa). SEM photos after bur grinding showed coarse scratches in random directions in terms of deep grooves and valleys in the specimens treated by bur. Although the appearance of roughened ceramic gave the impression of a considerably retentive surface, the results provided the lowest SBS values of the 4 conditioning methods. It is possible that these aggressive impingements induced chipping, loss of ceramic material, heat and residual stresses which initiated strength-reducing flaws jeopardizing the ceramic-adhesive bond strength (20).

Sometimes, ARI scores do not correlate with bond strength values (23,30); this was true in this study, also. The groups with the highest bond strength values had lowest ARI scores implying a flow in the ceramic-adhesive bond integrity. Therefore, one cannot estimate the site of bond failure by a definite shear force. Despite the SEM images and higher SBS values which implied improved retention capabilities, significantly lower ARI scores were detected for Group 1. This could be due to the impact of the sand particles with the surface creating median, lateral and radial cracks compromising the integrity of the ceramic (31). ARI scores indicated higher frequency of bond failure at the bracket-adhesive interface for Groups 2, 3 and 4 . Group 3 provided the most favorable results in terms of ARI scores: the resin predominantly adhered to the ceramic surfaces after debonding which is ideal for protecting the integrity of the ceramic restoration during debonding whereas in Group 1 cleanup after bracket debonding from the ceramic surface would be simplified because of greater quantity of the adhesive remnant being present on the bracket base. Simultaneous interpretation of SBS and ARI scores suggests that mechanical surface conditioning achieved by particle removal from the ceramic surface is more effective than chemical conditioning in agreement with previous studies $(21,32)$, whereas chemical bond achieved via the incorporation of silane caused failure to occur more frequently within the adhesive at the bracket-adhesive interface.

Although, intraoral degradation factors have been reported to compromise the integrity of adhesives and thermal cycling has been recommended in simulation of the artificial aging methods. There are conflicting results pertaining to the effects of thermocycling on SBS in terms of causing a significant influence on bond strength (33). Thus, in the cur- 
rent study, the specimens were not thermocycled similar to Reicheneder et al. study (34).

Futhermore, similar studies have tested various surface conditioning methods to different restorative materials $(35,36,37)$. Li et al. (35) investigated lithium disilicate ceramics with two resin cements after thermocycling and revealed that $\mathrm{HF}$ acid etching combined with a silane showed the highest SBS values. This study also point out that chemical bonding is more resistant to thermal damage than micromechanical interlocking. Another study by Colombo et al. (36) who also investigated the effects of surface pretreatments but on three diferent yttria-stabilized tetragonal zirconia polycrystalline ceramics presented that while air-borne particle abraded samples have reached the highest SBS values, the lowest values were obtained from the etched groups. Moreover, Chauhan et al. (37) invastigated the effect of dentin surface treatment with aluminum oxide air abrasion and Er:YAG laser when bonding to metal crowns by using tensile bond strength test and found that Er:YAG laser treated dentin showed superior tensile bond strenght values when compared to untreated dentin and air abraded dentin.

Consultation of laboratory studies prior to making recommendations for clinical use is the routine practice. However, there are limitations associated with the present study. Since it is impossible to neutralize all other confounding variables in the intraoral conditions and isolate only the conditioning methods, in-vitro studies possibly enable more standardized procedures with immaculate evaluation of the fact that is under question. Another limitation is only a few materials were tested and no aging procedure was performed. While in-vitro findings cannot be directly translated into clinical performances nor laboratory settings can fully reproduce clinical situations, yet they are a significant predictor of the potential outcomes.

In the current study, we observed that MEP can be an alternative for CoJet Sand and HF. Moreover, CoJet Sand and HF use require rubber dam because of the potentially hazardous effects on lungs (10) and gingiva (19) respectively, whereas MEP does not require a precaution to be taken or necessitate additional instrument. Furthermore, bonding brackets using a conventional adhesive requires a completely dry operative field, and persistent protein contamination from saliva was shown to hinder adhesion of resin cements to ceramics. However, in many instances, a wet environment is unavoidable. In a most recent study, it was reported that MEP was able to recover the bonding capacity similar to non-contaminated surfaces by removing saliva contamination (26).

\section{Conclusion}

Within the limitations of this in-vitro study, the following conclusions can be drawn: Considering the mean SBS values, all treatment methods except use of a diamond bur followed by a silane coupling agent can all be used for the bonding of metal brackets to the FC restorations with sufficient SBS for clinical performance. HF used in combination with silane coupling agent was found to be the most effective method in terms of preserving the integrity of the ceramic and clinical bonding performance since the adhesive mainly remained on the ceramic surface. The clinical appli- cation of MEP has been found promising since it presented with comparably high SBS values to CoJet and HF with safe ARI scores. Also, it eliminates the need for extra steps, minimizing the probability of contamination or the necessity to purchase additional instruments but also excludes potential detrimental effects of HF or sandblasting.

Türkçe Özet: Farklı Yüzey Işlemleri Uygulanmış Feldspatik Seramiklere Metal Braketlerin Makaslama Bağlanma Kuvvetinin Değerlendirilmesi: In vitro Çalışma. Öz: Feldspatik seramik (FS) yüzey işlemleri, braket yapıştırma için birçok adım gerektirmektedir. Hidroflorik (HF) asit ve kumlama ile karşılaştıııldığında, Monobond Etch \& Prime (MEP)'ın ağız içi kullanımı daha uygundur. Amaç: Bu çalışmada, organik rezinler ve seramik arasındaki bağlanma dayanıklıı̆ını arttırmak amacıyla üretilen MEP'in, lösit ile güçlendirilmiş FS yüzeyi ve metal braketlerin makaslama bağlanma kuvvet (MBK) değerleri üzerine olan etkisinin değerlendirilmesi amaçlandı. Gereç ve yöntem: FS materyalinden üretilen 40 adet örnek glaze işlemi sonrasında rastgele 4 yüzey işlem grubuna ayrıldı: (1) Kumlama (CoJet Sand); (2) MEP; (3) HF asit+silan; (4) Elmas frez+silan. MBK testi için universal test cihazı kullanıldı. Artık adeziv indeks (ARI) skorları tespit edildi. Bulgular: Gruplar arasında MBK'de istatistiksel olarak anlamlı bir fark $(p>0,05)$ bulunmazken, ARI skorları açısından gruplar arası anlamlı farklılık tespit edildi $(p<0,001)$. Grup 1 için, braket tabanında kalan adeziv yüzdesinin daha büyük olduğu ve yapışkan ara yüzünde başarısızlık modunu gösteren ARI skoru 1 ve 2 verildi. Diğergruplar daha yüksek ARI skoru olan 3 ve 2 aldı. FS yüzeyinde kalan ARI miktarı Grup 3'te en yüksek oldu, bunu Grup 4 ve Grup 2 izledi. Sonuç: MEP, metal braketlerin FS yüzeyine yapıştırılması için uygun bir alternatif olabilir. Klinik Önem: Yüksek MBK değerleri, daha güvenli ARI skorları ve çalışma alanının izolasyonu gibi ek bir önlem gerektirmeyen MEP, metal braketlerin FS yüzeyine yapıştırılmasında umut verici bulunmuştur. Anahtar Kelimeler: Yüzey işlem yöntemleri, Adezyon, Bağlanma kuvveti, Feldspatik seramik

Ethics Committee Approval: Not required.

Informed Consent: Not required.

Peer-review: Externally peer-reviewed.

Author contributions: DR, BY, EC, and IA designed the study. DR, BY, $E C$, and IA participated in generating the data for the study DR, BY, and IA participated in gathering the data for the study. DR and BY participated in the analysis of the data. DR wrote the majority of the original draft of the paper. DR, BY, EO, EC, and IA participated in writing the paper. All authors approved the final version of this paper.

Conflict of Interest: The authors of the current article certify that they have no affiliations with any organization or entity with any financial interest.

Financial Disclosure: The authors declared that they have received no financial support.

\section{References}

1. American Association of Orthodontists. A study to smile about: new study shows record number of adults are seeking orthodontic treatment, 2016.

2. Hosseini MH, Sobouti F, Etemadi A, Chiniforush N, Shariati M. Shear bond strength of metal brackets to feldspathic porcelain treated by Nd:YAG laser and hydrofl uoric acid. Lasers in Medical Science 2015;30:837-41. [CrossRef]

3. Spear F, Holloway J. Which all-ceramic system is optimal for anterior esthetics? Journal of the American Dental Association 2008;139:19-24. [CrossRef]

4. Denry I, Holloway JA. Ceramics for Dental Applications: A Review. Materials 2010;3:351-8. [CrossRef]

5. Stasinopoulos D, Papageorgiou SN, Kirsch F, Daratsianos N, Jager A, Bourauel C. Failure patterns of different bracket systems and 
their influence on treatment duration: A retrospective cohort study. The Angle Orthodontist 2018;88:338-47. [CrossRef]

6. Scribante A, Contreras-Bulnes R, Montasser MA, Vallittu PK. Orthodontics: Bracket Materials, Adhesives Systems, and Their Bond Strength. Biomed Research International 2016;2016:1-3. [CrossRef]

7. Sarac YS, Kulunk T, Elekdag-Turk S, Sarac D, Turk T. Effects of surface-conditioning methods on shear bond strength of brackets bonded to different all-ceramic materials. European Journal of Orthodontics 2011;33:667-72. [CrossRef]

8. Alakus Sabuncuoglu F, Erturk E. Shear bond strength of brackets bonded to porcelain surface: in vitro study. Journal of Istanbul University Faculty of Dentistry 2016;50:9-18. [CrossRef]

9. Ozcan M, Allahbeickaraghi A, Dundar M. Possible hazardous effects of hydrofluoric acid and recommendations for treatment approach: a review. Clinical Oral Investigations 2012;16:15-23. [CrossRef]

10. Schmalz G, Bindslev DA. Biocompatibility of Dental Materials. Springer-Verlag Berlin Heidelberg, 2009.

11. Peterson IM, Pajares A, Lawn BR, Thompson VP, Rekow ED. Mechanical characterization of dental ceramics by hertzian contacts. Journal of Dental Research 1998;77:589-602. [CrossRef]

12. Elsaka SE. Influence of surface treatments on bond strength of metal and ceramic brackets to a novel CAD/CAM hybrid ceramic material. Odontology 2016;104:68-76. [CrossRef]

13. Zachrisson BU. Orthodontic bonding to artificial tooth surfaces: clinical versus laboratory findings. American Journal of Orthodontics and Dentofacial Orthopedics 2000;117:592-4. [CrossRef]

14. Bishara SE, Ajlouni R, Laffoon JF, Warren JJ. Comparison of shear bond strength of two self-etch primer/adhesive systems. The Angle Orthodontist 2006;76:123-6.

15. Artun J, Bergland S. Clinical trials with crystal growth conditioning as an alternative to acid-etch enamel pretreatment. American Journal of Orthodontics 1984;85:333-40. [CrossRef]

16. Cevik P, Eraslan O, Eser K, Tekeli S. Shear bond strength of ceramic brackets bonded to surface-treated feldspathic porcelain after thermocycling. The International Journal of Artificial Organs 2018;41:160-7. [CrossRef]

17. Sarac YS, Elekdag-Turk S, Sarac D, Turk T. Surface conditioning methods and polishing techniques effect on surface roughness of a feldspar ceramic. The Angle Orthodontist 2007;7:723-8. [CrossRef]

18. Asiry MA, AIShahrani I, Alaqeel SM, Durgesh BH, Ramakrishnaiah R. Effect of two-step and one-step surface conditioning of glass ceramic on adhesion strength of orthodontic bracket and effect of thermo-cycling on adhesion strength. Journal of the Mechanical Behavior of Biomedical Materials 2018;84:22-7. [CrossRef]

19. Anusavice KJ, Shen C, Rawls HR. Phillips' Science of Dental Materials. Elsevier/Saunders: St. Louis, Mo, 2014.

20. Albakry M, Guazzato M, Swain MV. Effect of sandblasting, grinding, polishing and glazing on the flexural strength of two pressable all-ceramic dental materials. Journal of Dentistry 2004;32:91-9. [CrossRef]

21. Thurmond JW, Barkmeier WW, Wilwerding TM. Effect of porcelain surface treatments on bond strengths of composite resin bonded to porcelain. The Journal of Prosthetic Dentistry 1994;72:355-9. [CrossRef]

22. Durgesh BH, Alhijji $S$, Hashem MI, Al Kheraif AA, Durgesh $P$, Elsharawy $M$, et al. Influence of tooth brushing on adhesion strength of orthodontic brackets bonded to porcelain. Biomedical Materials and Engineering 2016;27:365-74. [CrossRef]

23. Karan S, Buyukyilmaz T, Toroglu MS. Orthodontic bonding to several ceramic surfaces: are there acceptable alternatives to conventional methods? American Journal of Orthodontics and Dentofacial Orthopedics 2007;132:144 e7-14. [CrossRef]

24. Schmage $P$, Nergiz I, Herrmann W, Ozcan M. Influence of various surface-conditioning methods on the bond strength of metal brackets to ceramic surfaces. American Journal of Orthodontics and Dentofacial Orthopedics 2003;123:540-6. [CrossRef]

25. Kolasinski K. Etching of silicon in fluoride solutions. Surface Science 2009;603:1904-11. [CrossRef]

26. Lyann SK, Takagaki T, Nikaido T, Wada T, Uo M, Ikeda M, et al. Efficacy of Various Surface Treatments on the Bonding Performance of Saliva-contaminated Lithium-Disilicate Ceramics. The Journal of Adhesive Dentistry 2019;21:51-8.

27. El-Damanhoury HM, Gaintantzopoulou MD. Self-etching ceramic primer versus hydrofluoric acid etching: Etching efficacy and bonding performance. Journal of Prosthodontic Research 2018;62:75-83. [CrossRef]

28. Borges GA, Sophr AM, de Goes MF, Sobrinho LC, Chan DC. Effect of etching and airborne particle abrasion on the microstructure of different dental ceramics. The Journal of Prosthetic Dentistry 2003;89:479-88. [CrossRef]

29. Politano G, Fabianelli A, Papacchini F, Cerutti A. The use of bonded partial ceramic restorations to recover heavily compromised teeth. The International Journal of Esthetic Dentistry 2016;11:314-36.

30. Ritter DE, Ritter AV, Bruggeman G, Locks A, Tulloch JF. Bond strengths and adhesive remnant index of self-etching adhesives used to bond brackets to instrumented and uninstrumented enamel. American Journal of Dentistry 2006;19:47-50.

31. Lawn BR. Fracture of brittle solids. Cambridge University Press. Cambridge, New York, 1993. [CrossRef]

32. Zhang ZC, Qian YF, Yang YM, Feng QP, Shen G. Bond strength of metal brackets bonded to a silica-based ceramic with lightcured adhesive: Influence of various surface treatment methods. Journal of Orofacial Orthopedics 2016;77:366-72. [CrossRef]

33. Inokoshi M, Kameyama A, De Munck J, Minakuchi S, Van Meerbeek B. Durable bonding to mechanically and/or chemically pre-treated dental zirconia. Journal of Dentistry 2013;41:170-9. [CrossRef]

34. Reicheneder CA, Gedrange T, Lange A, Baumert U, Proff $P$. Shear and tensile bond strength comparison of various contemporary orthodontic adhesive systems: an in-vitro study. American Journal of Orthodontics and Dentofacial Orthopedics 2009;135:422 e1-6. [CrossRef]

35. Li R, Ma SQ, Zang CC, Zhang WY, Liu ZH, Sun YC, et al. Enhanced bonding strength between lithium disilicate eramics and resin cement by multiple surface treatments after thermal cycling. PLoS ONE 2019;14:e0220466. [CrossRef]

36. Colombo M, Gallo S, Padovan S, Chiesa M, Poggio C, Scribante A. Influence of Different Surface Pretreatments on Shear Bond Strength of an Adhesive Resin Cement to Various Zirconia Ceramics. Materials (Basel) 2020;13:E652. [CrossRef]

37. Chauhan S, Mahajan N, Sethuraman R, Naveen YG. Evaluation of the effect of dentin surface treatment by air abrasion and Er:YAG laser on the retention of metal crowns luted with glass ionomer cement in teeth with reduced crown height: An in vitro study. The Journal of Indian Prosthodontic Society 2019;19:141-8. [CrossRef] 